\title{
The disappearance of cultural landscapes: the case of wooded-meadows in the Ligurian Apennines (NW Italy)
}

\author{
Chiara Molinari ${ }^{\mathrm{a}^{*}}$, Carlo Montanari ${ }^{\mathrm{b}}$ \\ ${ }^{a}$ Department of Physical Geography and Ecosystem Science, Lund University, Sölvegatan 12, 22362 Lund, Sweden \\ ${ }^{b}$ Department of Earth, Environmental and Life Sciences, University of Genoa, Corso Europa 26, 16132 Genoa, Italy
}

\section{A R T I CLE INFO}

\section{Article history:}

Received: $30^{\text {th }}$ May 2018

Accepted: $29^{\text {th }}$ November 2018

DOI: http://dx.doi.org/ 10.24916/iansa.2018.2.3

\section{Key words:}

pollen and charcoal analyses

historical topographic maps and documents

historical aerial and ground level photos

natural resources management

Fagus sylvatica $\mathrm{L}$.

\begin{abstract}
A B S T RACT
The "wooded-meadows system" is a multifunctional use of vegetation resources widespread in Europe since the Neolithic, and well documented in the Ligurian Apennines (NW Italy) between the Middle Ages and the first half of the $19^{\text {th }}$ century. The management of wooded-meadows included: collection of fallen and dead branches in spring, later used for fuel; mowing and grazing in summer; collection of secondary products; making sheaves from branches in autumn, later used as cattle and sheep fodder; coppicing, pollarding and cutting of trees in winter.

Three sites located in eastern Ligurian Apennines were studied by means of an interdisciplinary approach in order to better understand the impact and the consequences of this historical landuse practice on vegetation structure and composition. In particular, based on specific features of palynological diagrams, it was possible to conclude that (compared to the post-cultural phase) when the wooded-meadows system was in use, all the sites were characterized by: (1) lower pollen percentages of trees; (2) higher pollen percentages of shrubs and herbs; (3) higher percentages of anthropogenic pollen indicators; (4) higher values of palynological richness.

This research also represents a contribution to issues of nature-conservation policy for the preservation of cultural landscapes.
\end{abstract}

\section{Introduction}

The management system commonly known as "woodedmeadows" consists of a multifunctional use of vegetation resources that has been widespread in Europe (particularly in the region around the Baltic Sea, and in the mountains of central and southern Europe) since the Neolithic (Sigaut, 1982; Rasmussen, 1990; Maggi, Nisbet, 2000). Woodedmeadows are generally defined as meadows with trees, or a combination of trees, grassland and tall-herb vegetation. Trees typically cover $10-50 \%$ of the ground, while 80 $90 \%$ can be mowed (Kull et al., 2003). Wooded-meadows were originally managed with a series of cyclical tasks (Figure 1) including: (a) the collection of fallen and dead branches in spring, later used for fuel; (b) mowing and grazing during summer; (c) the collection of secondary products (e.g. berries, mushrooms, medicinal herbs, etc.) in autumn; (d) making sheaves from branches and twigs (after hay-making), later dried and used for cattle and sheep fodder in winter; (e) coppicing, pollarding and cutting of trees in winter (Moreno, Raggio, 1990; Read, 2000; Grove, Rackham, 2001). The outcome of such an extensive form of land-use was a highly productive system providing wood, grass, leaf-hay and fruits, with a consequent maintenance of fertility and increase of species diversity (Kukk, Kull, 1997; Peterken, 2017).

Within this context, our main aim was to better understand the main consequences of this land-use practice on vegetation structure and composition in the past. By means of an interdisciplinary approach, we studied three different sites located in eastern Ligurian Apennines (Figure 2), an area where the management of wooded-meadows was widespread between the Middle Ages and the first half of the $19^{\text {th }}$ century, but which has since disappeared (Moreno, 1990; Lowe et al., 1994; Davite, Moreno, 1996; Moreno, Poggi, 1996; Cevasco, 2007). 

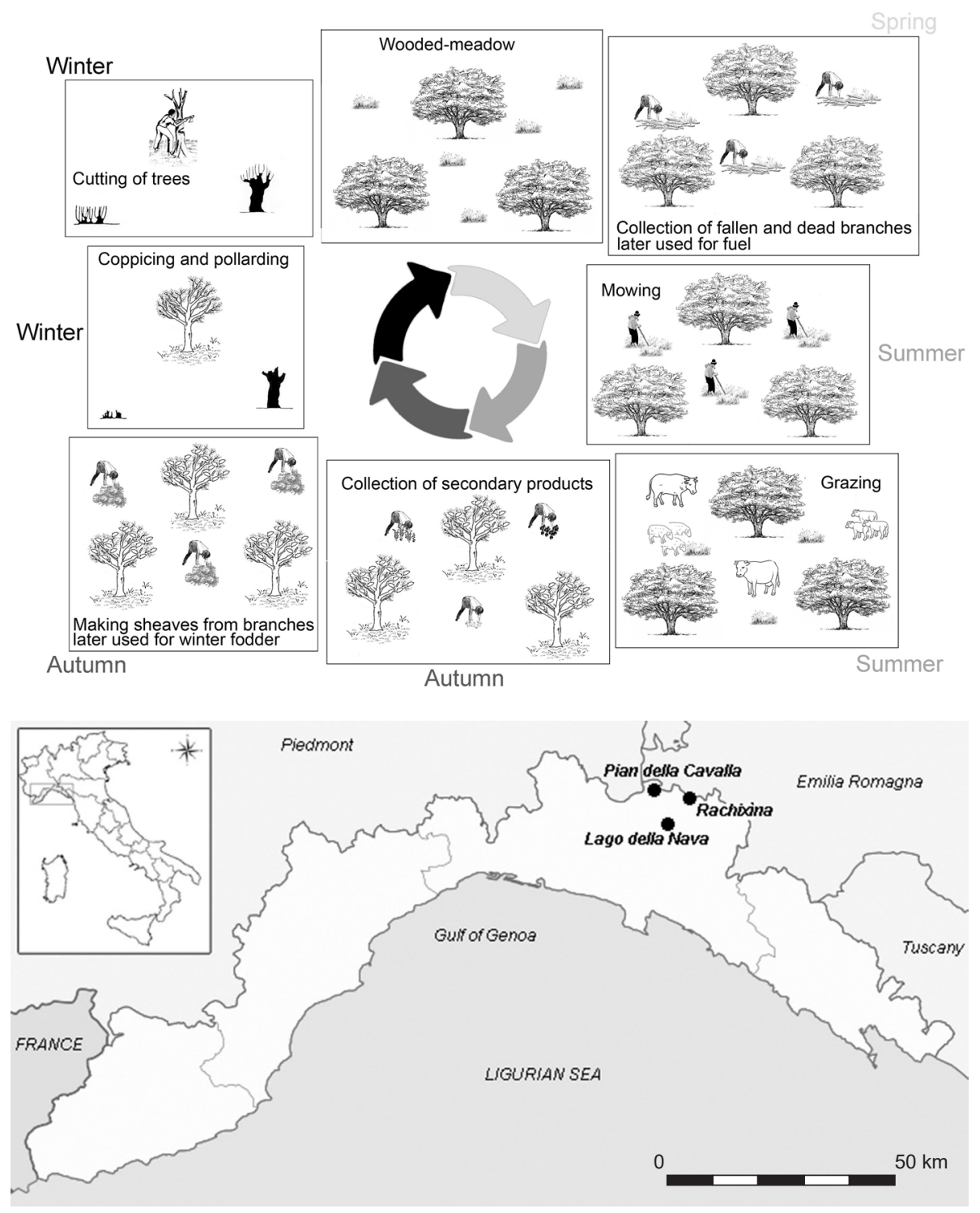

Figure 1. Different tasks included in the cyclical management of wooded-meadows.

Figure 2. Location map of the study sites.

\section{Methodology}

\subsection{Site selection and description \\ 2.1.1 Pian della Cavalla}

UTM 32T, WGS84: 518570 E; 4936939 N, 1267 m asl, Figures 2 and $3 \mathrm{a}$. This site is located in the Trebbia Valley, eastern Ligurian Apennines. Today the site is a hay meadow, with scattered beech groves, characterised by the presence of a small pond, completely dry in summer. The grassland is rich in Poaceae (i.e. Brachypodium rupestre Hudson, Festuca pratensis L., Phleum pratense L., Avenella flexuosa (L.) Drejer) and many other herb species such as Genista tinctoria L., Asphodelus albus Mill., Hypericum perforatum L., Leucanthemum vulgare Lam., Arnica montana L., Valeriana officinalis L., Orchis mascula L. and Narcissus poeticus L. The small pond hosts species typical of temporary wet soils such as Carex vesicaria L., Carex vulpina L., Heleocharis palustris (L.) Roem. \& Schult, Galium palustre L., Ranunculus repens L. and Potentilla erecta (L.) Raeuschel.

\subsubsection{Lago della Nava}

UTM 32T, WGS84: 523975 E; 4929041 N, 1165 m asl, Figures. 2 and $3 \mathrm{~b}$. This site is located on the watershed between the Trebbia and Aveto Valleys, eastern Ligurian Apennines. Currently the sampling site is a temporary pond, dry in summer, dominated by Polygonum arenastrum Boreau and Spergularia rubra (L.) C. Presl. The surrounding vegetation is characterized by Fagus sylvatica L. woodlands, with presence of Acer pseudoplatanus L., Sorbus aria (L.) Crantz, S. aucuparia L., Fraxinus ornus L., Laburnum alpinum (Miller) Berchtold et Presl, Quercus cerris L., Pyrus piraster Burgsd., Prunus avium L., Salix caprea L. In open areas, shrubs such as Calluna vulgaris (L.) Hull, Genista pilosa L., Juniperus communis L., Prunus spinosa L., Crataegus monogyna Jacq., Rosa canina L., Vaccinium myrtillus L. and Cytisus scoparius (L.) are also common. Of particular interest, between the post-medieval period and the first half of the $20^{\text {th }}$ century, the area was part of an extensive network of transhumance routes. Furthermore, today the site is located inside the SIC- 
Figure 3. Present-day situation at the selected Fagus sylvatica L. woodedmeadows. a) Pian della Cavalla, b) Lago della Nava, c) Rachixina. In a) and b) the wetland area is underlined in blue. Pictures: C. Molinari, 2008.

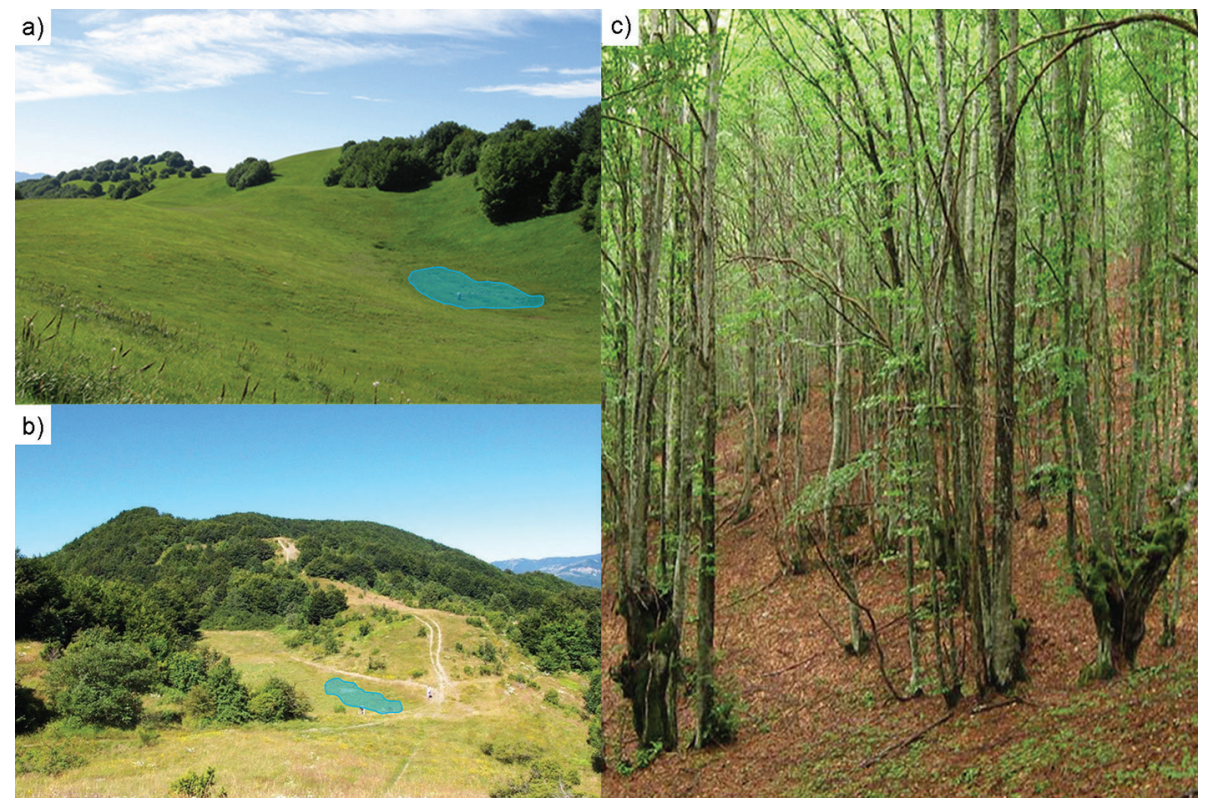

ZSC (i.e. Site of Community Importance-Special Zone of Conservation) IT1331012 "Lago Marcotto - Roccabruna - Gifarco - Lago della Nave" and is included in the Natura 2000 network. Evidence of the ancient wooded-meadows are visible today thanks to the presence in the surroundings of old pollarded beeches. Additionally, close to the site, there are still some "casoni", traditional buildings widespread in the Ligurian Apennines between the $17^{\text {th }}$ and the $20^{\text {th }}$ century used as a refuge for shepherds and animals during the night.

\subsubsection{Rachixìna}

UTM 32T, WGS84: 527888 E; 4934310 N, 1334 m asl, Figures 2 and 3c. This site is located between the Trebbia and Aveto Valleys, eastern Ligurian Apennines. Today the site is a woodland with ancient pollarded beech trees, completely abandoned, with a very poor understory characterised by nitrophilous and synanthropic species (e.g. Polygonatum verticillatum (L.) All., Geranium robertianum L., Galeopsis tetrahit L. and Galeopsis speciosa Miller). Moreover, the presence of many centuries-old large pollarded beeches is a memory of past management practices related to the use of wooded-meadows in the area. Furthermore, the occurrence of the epiphytic lichen Lobaria pulmonaria (L.) Hoffm., commonly associated with the presence of ancient trees, suggests the high conservation priority of the site (Rolstad et al., 2001; Nascimbene et al., 2013). Actually Rachixina is located inside the SIC-ZSC IT1331012 "Lago Marcotto Roccabruna-Gifarco - Lago della Nave" and is included in the Natura 2000 network.

\subsection{Historical documents}

The comparison of historical topographic maps, historical aerial photos, historical photos and historical archival documents dated back to the last $c a .150$ years allowed the reconstruction of the most important vegetation and land- use changes at the three selected sites. This approach, based on the use of different sources, has already provided good results in the past within our research group (Cevasco, 2007; Poggi, 2013; Molinari, Montanari, 2016).

\subsection{Field and laboratory methods}

Each selected site was studied through biostratigraphic analyses with the aim of identifying specific palynological assemblages associated with the wooded-meadows system. While at Pian della Cavalla and Lago della Nava we cored the wetland area, at Rachixina - due to the absence of nearby wetlands - a soil profile was sampled. Lithology and stratigraphy were recorded in the field, and soil $\mathrm{pH}$ (determined in $\mathrm{H}_{2} \mathrm{O}$ ) was measured using a standard technique (Thunjai, Boyd, 2001).

At Pian della Cavalla and Lago della Nava sub-samples ( $2 \mathrm{~cm}^{3}$ volume) for pollen and microcharcoal analysis were extracted every $5 \mathrm{~cm}$ between 0 and $30 \mathrm{~cm}$, and every $10 \mathrm{~cm}$ between 30 and $50 \mathrm{~cm}$. At Rachixina the samples were extracted from $0,1,2.5,5,8,13,23,28,32,38,43,48,53$, 58, 63 and $68 \mathrm{~cm}$ deep. Lycopodium tablets were added to the samples (Stockmarr, 1971), which were processed using standard laboratory procedures (Moore et al., 1991). Due to the generally low concentration (calculated as number of grains/gram of sediment), a minimum of 200 pollen grains (excluding fern spores) were counted at each level; the minimum number of grains necessary for a statisticallyvalid count was therefore reached (Barkley, 1934; Bryant, Holloway, 1983). Microcharcoals between 10 and $200 \mu \mathrm{m}$ were counted in pollen slides.

Pollen identification follows the keys and illustrations in Moore et al. (1991) and Reille (1992-1995), and the reference pollen collection at the University of Genoa.

One sample of each profile was sent to the Beta Analytic Dating Laboratory of Miami (Florida) for accelerator mass spectrometry (AMS) radiocarbon dating. Furthermore, for the Rachixina soil profile, three additional dates were 


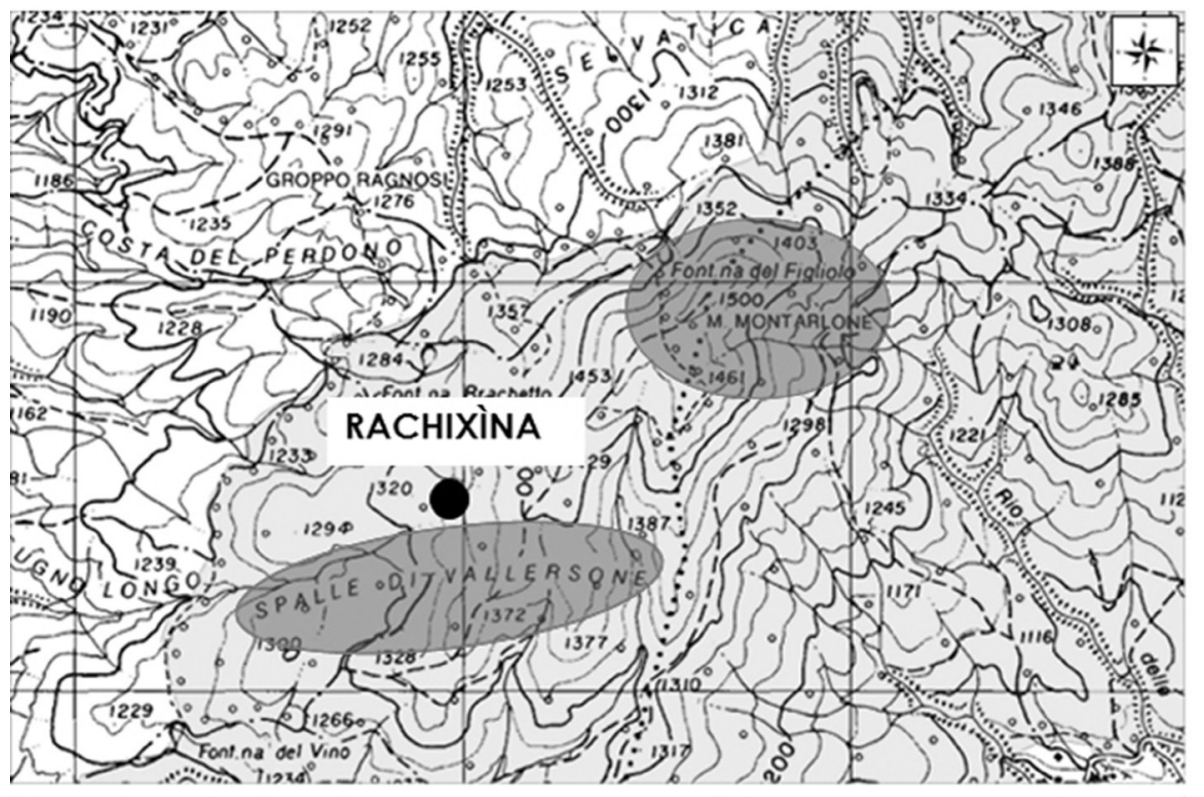

\begin{tabular}{|c|c|c|c|}
\hline Site & Year & Management action & Species \\
\hline \multirow{5}{*}{$\begin{array}{l}\text { Below } \\
\text { M. Montarlone }\end{array}$} & 1953 & Reforestation & black pine \\
\hline & 1956 & Reforestation & red oak \\
\hline & 1958 & Reforestation & black pine+silver fir+red oak \\
\hline & 1967 & Cut of branches & beech \\
\hline & 1970 & Reforestation & silver fir+ black pine \\
\hline \multirow{5}{*}{ M. Montarlone } & 1927 & Auction for wood sale & beech \\
\hline & 1930 & $\begin{array}{l}\text { Authorization for the } \\
\text { ignition of charcoal piles }\end{array}$ & beech \\
\hline & 1950 & Auction for wood sale & beech \\
\hline & 1950 & $\begin{array}{l}\text { Authorization for the } \\
\text { ignition of charcoal piles }\end{array}$ & beech \\
\hline & 1955 & Reforestation & $\begin{array}{l}\text { silver fir+Norway spruce+ black } \\
\text { pine }\end{array}$ \\
\hline $\begin{array}{l}\text { Fontana del } \\
\text { Figliolo }\end{array}$ & 1930 & $\begin{array}{l}\text { Authorization for the } \\
\text { ignition of charcoal piles }\end{array}$ & beech \\
\hline \multirow{3}{*}{$\begin{array}{l}\text { Spalle di } \\
\text { Vallersone }\end{array}$} & 1930 & $\begin{array}{l}\text { Authorization for the } \\
\text { ignition of charcoal piles }\end{array}$ & beech \\
\hline & 1950 & Auction for wood sale & beech \\
\hline & 1965 & Reforestation & silver fir+ black pine \\
\hline
\end{tabular}

Figure 4. Information collected from the historical archival documents in the area close to Rachixina and the location of the sites listed in the table (Carta Tecnica Regionale, scale 1: 25 000). The information used for dating some variations in the palynological diagram are highlighted in bold. assigned thanks to the information collected from some historical documents concerning reforestation practices and authorizations for the ignition of charcoal piles (Figure 4). The AMS radiocarbon ages were calibrated to calendar years $\mathrm{BP}(0 \mathrm{BP}=\mathrm{AD} 1950)$ using the software OxCal 3.10 (Bronk Ramsey, 2005) and the IntCal04 calibration curve
(Reimer et al., 2004). The most likely probability within the $2 \sigma$ calibrated results ( $95.4 \%$ confidence range) was used for chronological control (Table 1). While for the clay sediments cored at Pian della Cavalla and Lago della Nava it was possible to assume a quite constant sedimentation rate and thus interpolate between the available dates for obtaining

Table 1. Details of the AMS radiocarbon dates.

\begin{tabular}{|c|c|c|c|c|c|}
\hline Site & Lab. ref & Depth (cm) & Material dated & Uncal. 14C-yr BP & $2 \sigma$ cal. results \\
\hline Pian della Cavalla & Beta-251988 & 50 & Bulk sediment sample & $2280 \pm 40$ & $\begin{array}{l}\text { cal BC } 390-360(68 \%) \\
\text { cal BC } 300-210(95 \%)^{*}\end{array}$ \\
\hline Lago della Nava & Beta-251990 & 50 & Bulk sediment sample & $1940 \pm 40$ & $\begin{array}{l}\text { cal BC } 30-\text { AD } 130(95 \%)^{*} \\
\text { cal AD } 20-90(68 \%)\end{array}$ \\
\hline Rachixina & Beta-2413A & 55 & Bulk soil sample & $2125 \pm 45$ & $\begin{array}{l}\text { cal BC } 360-280(15.6 \%) \\
\text { cal BC } 260-40(79.8 \%)^{*}\end{array}$ \\
\hline
\end{tabular}

*Most likely probability 

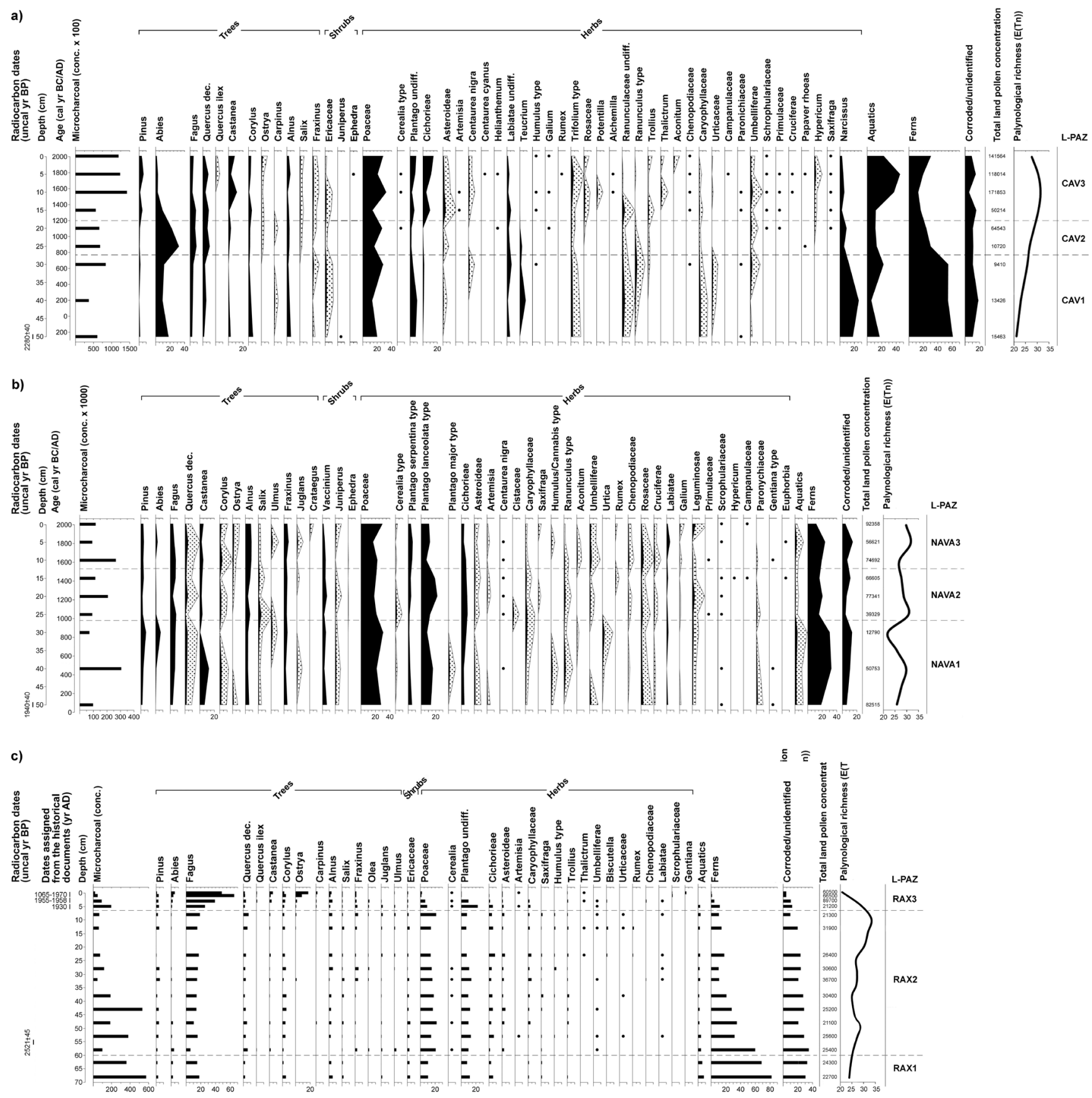

Figure 5. Simplified palynological diagrams for Pian della Cavalla (a), Lago della Nava (b) and Rachixina (c). Analyses by C. Molinari.

an estimated continuous chronology, for the Rachixina' soil profile such interpolation was impossible.

Summary pollen percentages were graphically displayed together with microcharcoal concentrations (Figures 5 and 6) using the software Tilia 2.0.41 (Grimm, 2015). Local pollen assemblage zones (hereafter L-PAZs) have been defined for each pollen diagram to facilitate the description and the interpretation of major vegetation and land-use changes (Figure 6).

Variation in palynological richness (Figures 5 and 6), a proxy for species richness (Oldfield, Dearing, 2003), was estimated using the rarefaction analysis technique (Birks,
Line, 1992). By removing the effect of different count sizes on the number of pollen taxa recorded, this method assesses the expected palynological richness if the pollen sum (usually the lowest total sum in the sequence) had been the same for each pollen sample (Odgaard, 2001).

\section{Results}

\subsection{Historical documents}

At Pian della Cavalla, the study of different topographic maps (Figure 7) from the last ca. 150 years allows the 


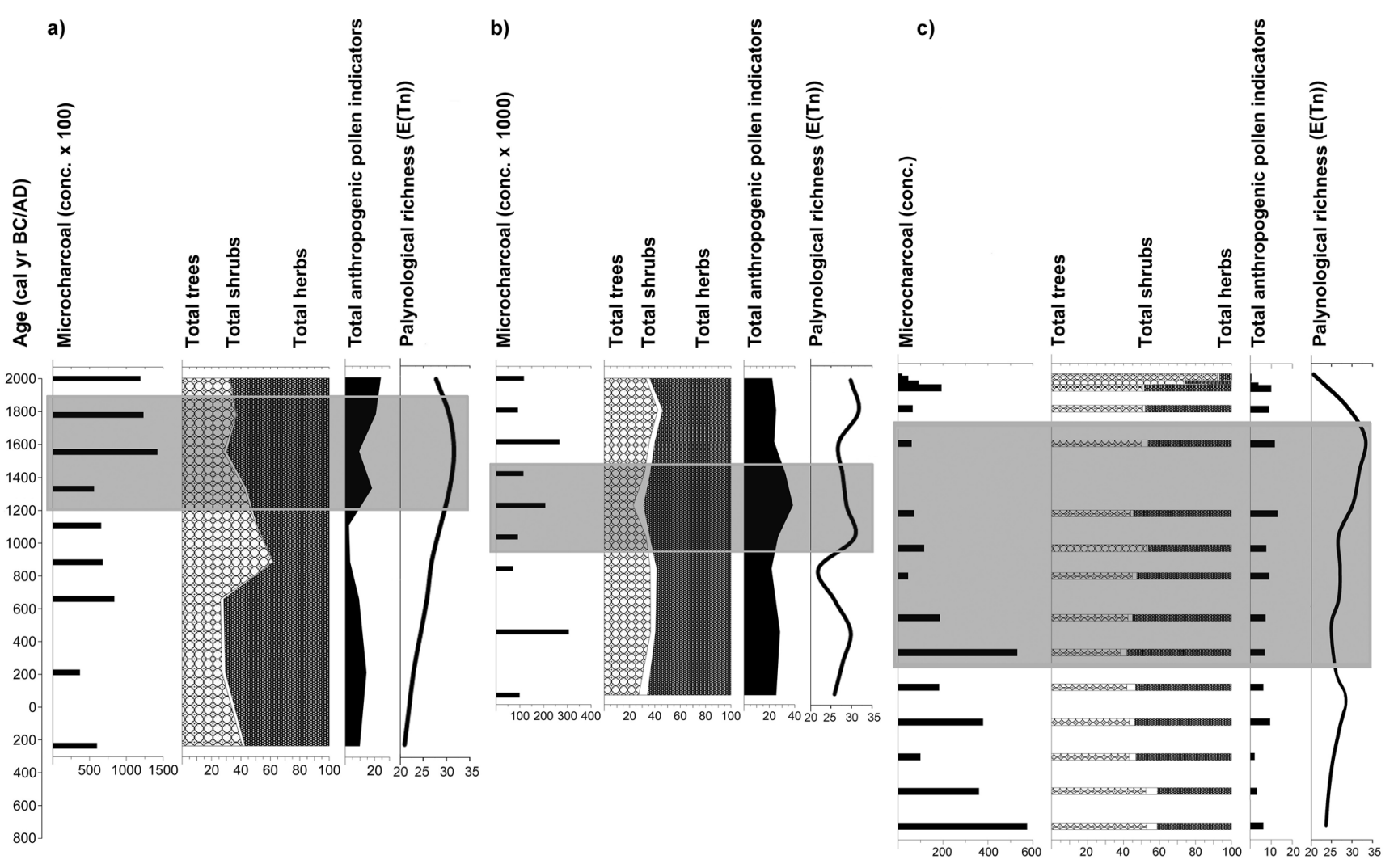

Figure 6. Summary pollen diagrams showing trends of total trees, shrubs, herbs and anthropogenic pollen indicators, together with microcharcoal concentrations and palynological richness for Pian della Cavalla (a), Lago della Nava (b), and Rachixina (c). The period when the wooded-meadows system was widespread in the selected sites is highlighted.

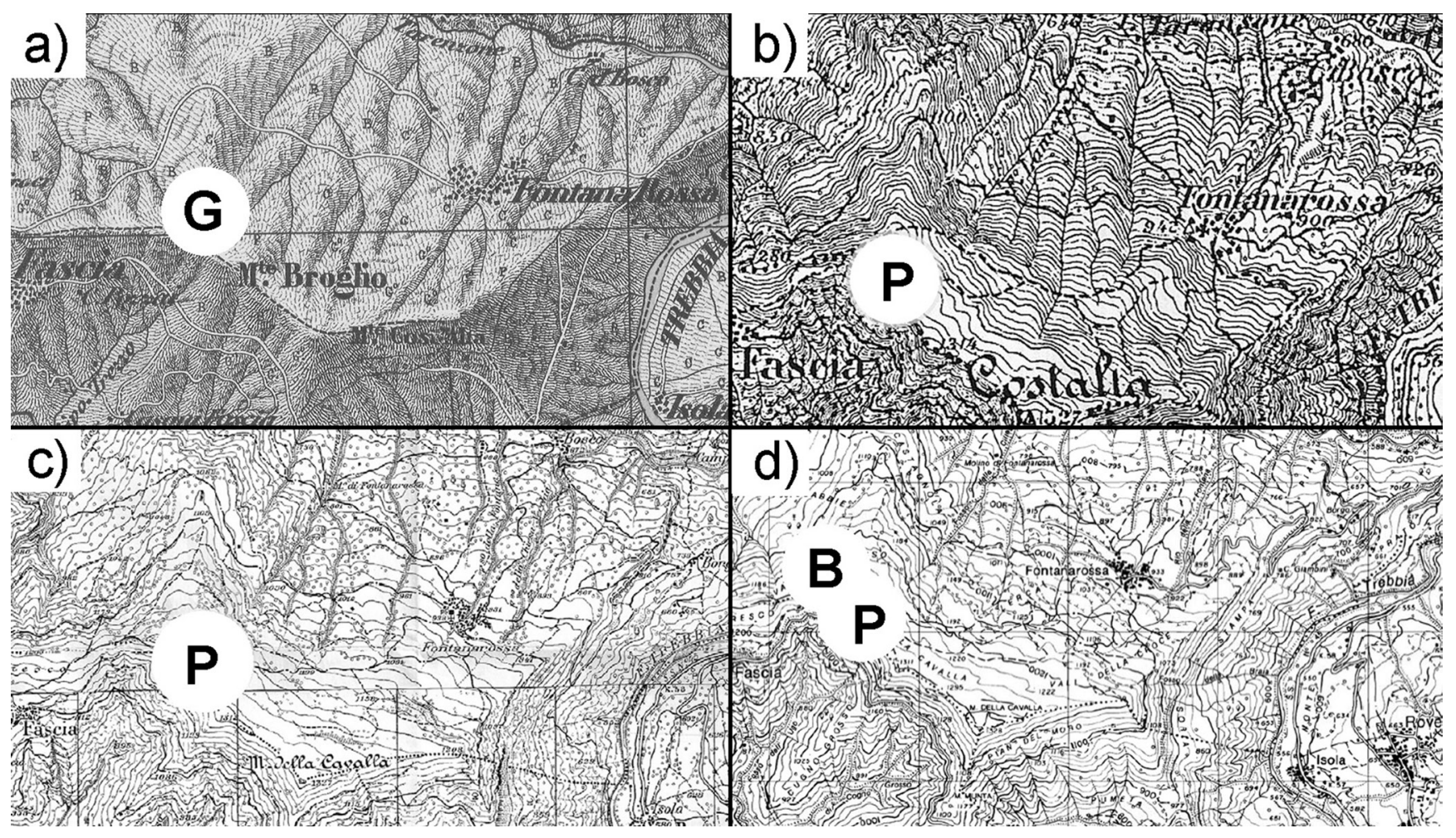

Figure 7. Historical topographic maps showing main land-use changes at Pian della Cavalla between 1852 and 1986. a) Gran Carta degli Stati Sardi in Terraferma, Corpo di Stato Maggiore Sardo (1852), scale 1: 50 000, sheet Torriglia; b) Istituto Geografico Militare - Firenze (1878), scale 1: 50 000, sheet Ottone; c) Carta d'Italia (1936), scale 1: 25 000, sheet 83; d) Carta Tecnica Regionale (1986), scale 1: 25 000, sheet Rovegno/Gorreto. G=gerbido (wood/ meadow), $\mathrm{P}=$ prato (meadow), $\mathrm{B}=$ bosco (woodland). 
Figure 8. Historical aerial photos from Pian della Cavalla. a) Istituto Geografico Militare - Firenze (1954), scale 1: 33 000; b) Regione Liguria, SP-GE (1995), scale 1: 13000 .
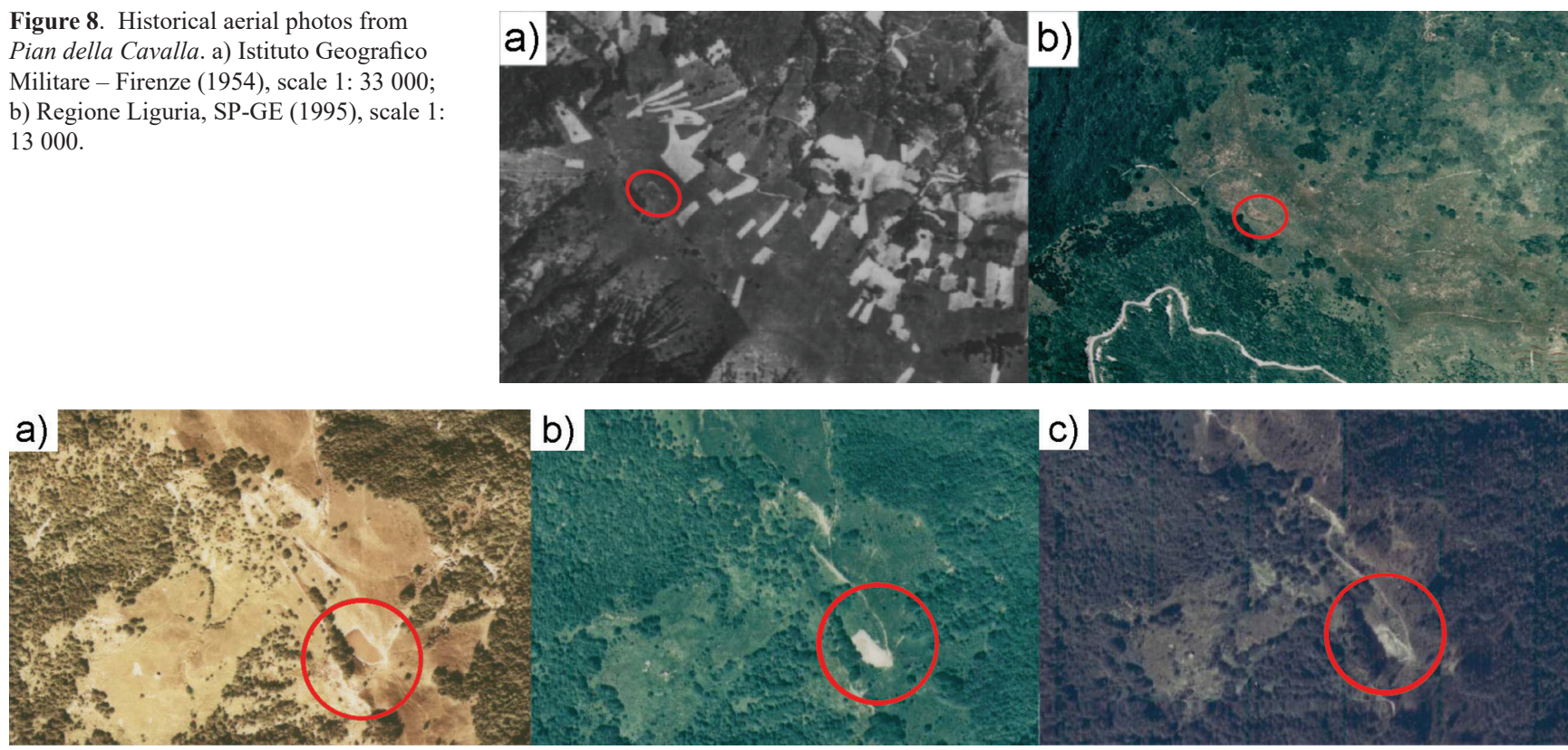

Figure 9. Historical aerial photos from Lago della Nava. a) Regione Liguria, SP-GE (1973), scale 1: 13 000; b) Regione Liguria, SP-GE (1995), scale 1: 10 000; c) Regione Liguria, TREB/FONT (1999), scale 1: 10000.

Figure 10. Historical photos from Lago della Nava. a) 1957, personal collection, Fontanigorda (GE); b) 1981, photo C Montanari; c) 2000, LASA archive; d) 2009, photo C. Molinari.

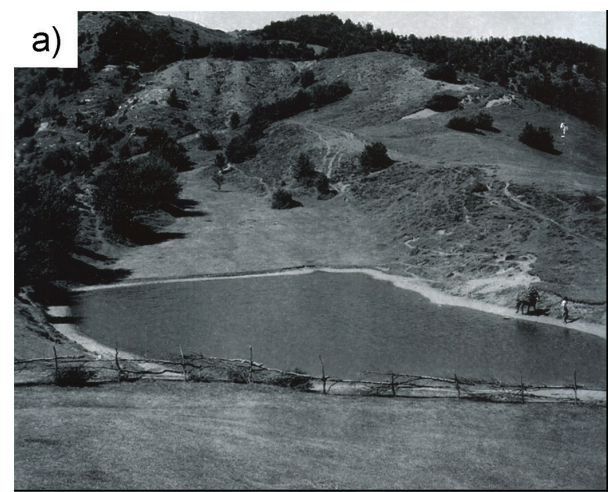

\section{c)}

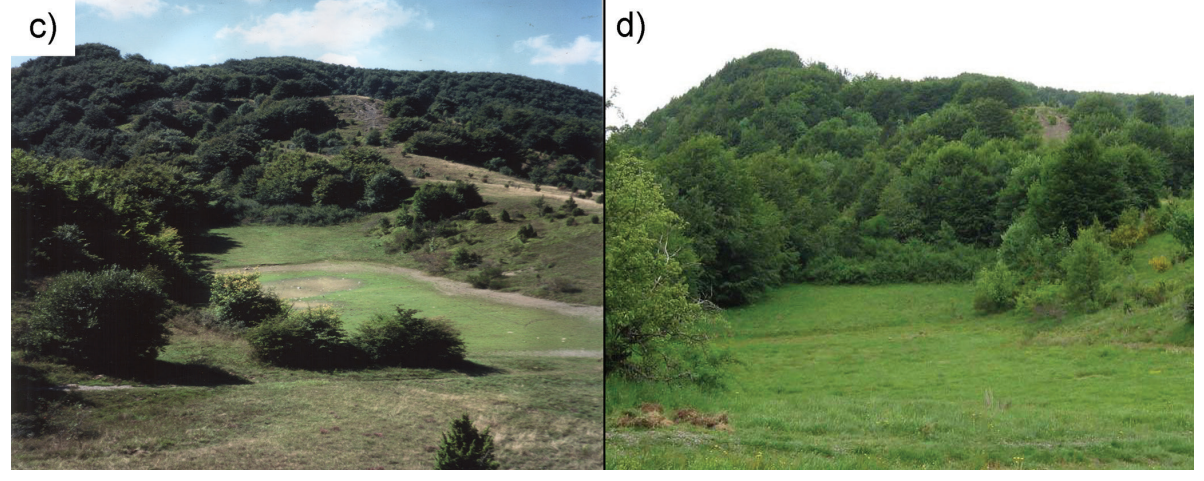

progressive retreatment of meadows and the expansion of woodlands to be highlighted. Similarly, the comparison between aerial photos dated 1954 and 1995 (Figure 8) shows the transformation of the landscape from patchy agricultural lands to a more homogenous arboreal vegetation.

At Lago della Nava, the comparison of historical aerial photos (Figure 9) and historical ground level photos (Figure 10) from the last ca. 60 years enabled the highlighting of the progressive reduction of the water basin, probably due to an increase in the arboreal vegetation surrounding the wetland and the replacement of pastures with woodlands (see also Gemignani, 2013).

At Rachixina, evidence about the past management of the area has been collected from historical archival documents. In particular, information concerning reforestation practices and the authorizing of the ignition of charcoal piles over the last $c a$. 80 years (Figure 4) have been used for dating some variations in the palynological diagram (Figures 5 and 6).

Furthermore, a handwritten map (scale 1: 9450; Figure 11) edited by the Sardinia Kingdom's military topographer 


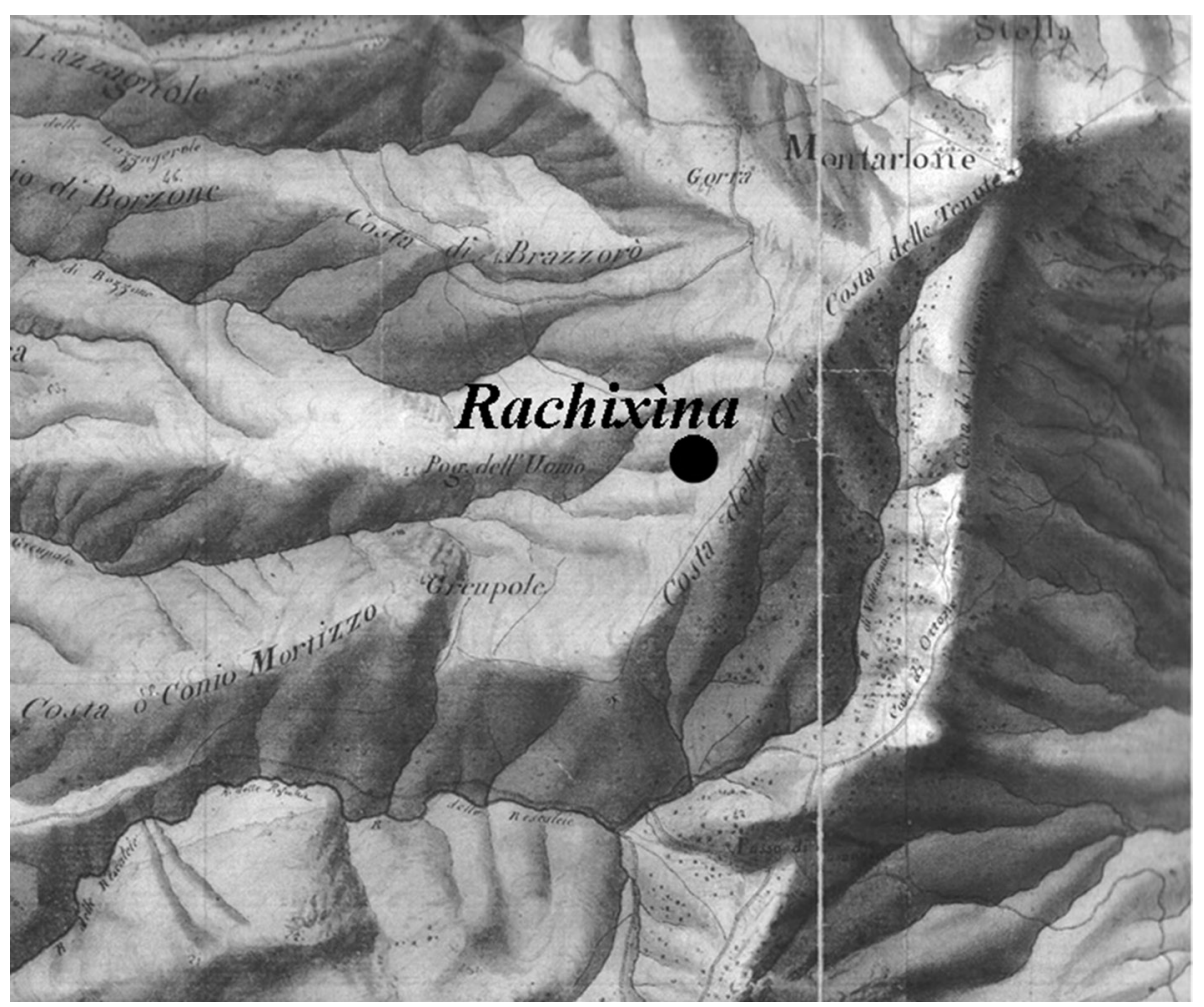

Figure 11 Handwritten map (scale 1: 1940) edited by the Sardinia Kingdom's military topographer Gustavo Scati describing the vegetation cover at Rachixina in 1827.

Gustavo Scati in 1827 shows - for the area surrounding Rachixina - a completely open landscape, without trees. In these kinds of maps land-use classification was based on the type of obstacle represented by the forest cover to the passage of military troops or for military manoeuvres (Cevasco, Moreno, 2007). This probably means that the trees present at Rachixina in 1827 were scattered and did not represent an obstacle for military operations (Cevasco, 2002).

\subsection{Biostratigraphical analyses}

Pian della Cavalla and Lago della Nava sediment profiles were similar in appearance, mainly clayey, grey or brown in colour according to the amount of organic matter and the oscillating water table. The Rachixina soil profile, by contrast, was characterised by a thick leaf-litter layer (Oahorizon), followed by a dark reddish-brown clay A-horizon and a thick C-horizon of clay with gravel (Table 2).

Pollen preservation was generally poor. Particularly for Rachixina, a pattern of increasing percentages of corroded/unidentified pollen grains with depth, together with decreasing pollen concentration in the lower samples, is explained by degradation of palynomorphs caused by oxidation processes, microbiological activity, and organic matter decomposition (Gavin, Brubaker, 1999; Wilmshurst,

Table 2. Description of the profiles sampled for pollen and microcharcoal analyses.

\begin{tabular}{|c|c|c|c|c|}
\hline Site & Depth (cm) & Description & $\mathrm{pH}\left(\mathrm{H}_{2} \mathrm{O}\right)$ & Munsell soil color \\
\hline \multirow{4}{*}{ Pian della Cavalla } & $0-2$ & Organic, herbaceous turf & - & - \\
\hline & $2-12$ & Clay horizon with high proportion of organic matter & 6,2 & $2.5 \mathrm{Y} 6 / 2$ \\
\hline & $12-33$ & Clay horizon with little proportion of organic matter & 6,8 & $2.5 \mathrm{Y} 7 / 2$ \\
\hline & $33-50$ & Sandy clay horizon (absence of organic matter) & 7,4 & $2.5 \mathrm{Y} 8 / 2$ \\
\hline \multirow{5}{*}{ Lago della Nava } & $0-1$ & Organic, herbaceous turf & - & - \\
\hline & $1-10$ & Clay horizon with little proportion of organic matter & 6 & $2.5 \mathrm{Y} 7 / 2$ \\
\hline & $10-16$ & Clay horizon with high proportion of organic matter & 6,7 & $2.5 \mathrm{Y} 7 / 2$ \\
\hline & $16-28$ & Clay horizon with little proportion of organic matter & 6,1 & $2.5 Y 7 / 2$ \\
\hline & $28-50$ & Sandy clay horizon (absence of organic matter) & 6 & $2.5 \mathrm{Y} 6 / 2$ \\
\hline \multirow{4}{*}{ Rachixina } & $0-5$ & Organic, highly decomposed (Oa) & - & - \\
\hline & $5-11$ & Clay horizon with high proportion of organic matter (A1) & 3,9 & $5 Y R 3 / 3$ \\
\hline & $11-48$ & Clay horizon with little proportion of organic matter (A2) & 4,2 & $5 Y R 3 / 3$ \\
\hline & $48-75$ & Clay horizon with gravel and absence of organic matter (C) & 3,9 & $5 Y R 3 / 3$ \\
\hline
\end{tabular}


McGlone, 2005). However, despite this, the acidity of the soil profile may have helped towards some level of preservation of pollen grains (Segerström, 1991; Dijkstra, van Mourik, 1995).

The pollen and microcharcoal analytical results are presented in three palynological diagrams, one for each study site (Figure 5). The downward changes in the diagrams, consistent with the vegetation and land-use history described by the historical sources, argue for similar processes occurring across the sites and for minimum bioturbation and mixing of the sequences.

At Pian della Cavalla (Figure 5a), the most ancient L-PAZ (CAV1, 27-50 cm; 200 BC-800 AD) is characterised by a quite open landscape, with abundant ferns. The main herbaceous species ( $\sim 65 \%$ of Total Land Pollen, hereafter TLP) are Narcissus, Poaceae, Plantago and Labiatae. Ericaceae have their maximum in this phase. The tree cover is dominated by Abies, an important component of northern Apennines mesophilous, mixed woodlands for most of the Holocene, until the Medieval period (Branch, 2004, Guido et al., 2013). Small percentages of Fagus, Corylus, Alnus, deciduous Quercus and Castanea are also present. Mean microcharcoal concentration and palynological richness are lower in comparison to more recent L-PAZs. CAV2 (17-27 cm; 800-1200 AD) is characterized by an increase in arboreal species (up to $60 \%$ of TLP), always dominated by Abies, with Fagus, deciduous Quercus, Corylus, Alnus and Castanea, while the Ericaceae decrease. Within the herbaceous component, Poaceae, ferns and Narcissus are dominant. Microcharcoal concentrations remain quite steady, while palynological richness increases. During the last phase (CAV3, 0-17 cm; 1200-2000 AD) arboreal species decrease again. This is mainly due to the post-medieval disappearance of Abies (present again - with Pinus and Picea - in the uppermost levels, testifying the reforestation practices carried out in the area during the second half of the $20^{\text {th }}$ century). The only tree showing an increase is Castanea, underlying the expansion of chestnut cultivation during this period. Ericaceae increase in the last phase. The herbaceous layer ( $\sim 65 \%$ of TLP) is dominated by Poaceae, Cichorieae, Plantago and Narcissus, with Cerealia. Aquatic species (especially Juncaceae and Cyperaceae) reach their maximum in this final phase. Both microcharcoal concentrations and palynological richness increase. The overall picture is thus quite similar to the present landscape.

At Lago della Nava (Figure 5b), the first L-PAZ (NAVA1, $28-50 \mathrm{~cm} ; \sim 80-1000$ AD) is dominated by herbaceous species ( $\sim 60 \%$ of TLP, mainly ferns and Poaceae, with Plantago and Cichorieae). The occurrence of a few Cerealia pollen grains is simultaneous with a peak in the microcharcoal concentration. The shrub component consists of Vaccinium and Juniperus. The arboreal species (33\% of TLP) mainly consist of Fagus, Castanea, Alnus and Fraxinus. The presence of Pinus pollen is probably of extra-local origin, while the peak in Abies coincides with the one recorded at Pian della Cavalla during the Medieval period. Palynological richness is low. During NAVA2 (12-28 cm; 1000-1500 AD) arboreal taxa, aquatics and ferns decrease, while a rise in herbaceous species and shrubs is recorded. Cerealia and palynological richness increase. The most recent phase (NAVA3, 0-12 cm; $\sim 1500-2000$ AD) is dominated by ferns, Poaceae, Plantago and Cichorieae. Aquatic species reach a peak around the second half of the $19^{\text {th }}$ century, and then decrease in recent times. Shrub percentages remain constant. Palynological richness is quite high, as in the previous L-PAZ. Regarding microcharcoal concentrations, their values are discontinuous during the whole recorded time span. This fact might be due to the occasional use of controlled fires for agricultural practices or for an opening up of new grazing areas

At Rachixina (Figure 5c), the most ancient L-PAZ (RAX1, 63-68 cm) is dominated by Fagus, with low occurrence of Corylus, Alnus, Quercus deciduous, Pinus and Abies. The high amount of ferns might indicate a high soil oxidation that caused a deterioration of pollen grains (Dimbleby, $1957)$. The herbaceous layer ( $30 \%$ of TLP) is characterised by the predominance of Poaceae, Plantago and Cichorieae. Ericaceae have their peak during this phase. Microcharcoal concentration is high, while palynological richness is lower than during the following L-PAZ. RAX2 $(8-58 \mathrm{~cm}$; $55 \mathrm{~cm}=260-40$ BC) is still dominated by Fagus, but with a higher amount of herbaceous species ( $40 \%$ of TLP). The presence of Cerealia pollen, the microcharcoal oscillations and the higher values of palynological richness support the hypothesis that agricultural practices (probably involving the use of controlled fires) were carried out close to the site. The last phase (RAX3, 0-5 cm; 1930-2000 AD) is characterised by a close forest canopy (arboreal pollen $>80 \%$ of TLP), still dominated by Fagus, with Ostrya, Corylus, Quercus deciduous, Alnus, Castanea, Fraxinus and planted Pinus. Herbs and shrubs decrease, and thus so does palynological richness. By contrast, microcharcoal concentration increases, probably due to the ignition of wood piles for the production of charcoal in beech woodlands documented by the historical sources (Figure 4).

\section{Discussion}

The present study can be considered as a first attempt to shed more light - by means of an interdisciplinary approach on the specific dynamics of past land-use connected to the management of beech wooded-meadows in the Ligurian Apennines.

Even if the comparison between biostratigraphical results (pollen and microcharcoal data) and historical sources (archival documents, topographic maps, ground photos and aerial photos) is not straightforward due to the different temporal and spatial scales, the vegetation dynamics recorded by the palynological sequences match quite well with the information collected for the last 200 years from other datasets. Certainly, an increase in the number of sediment/soil samples analysed and of radiocarbon dates for each profile would have improved the reliability of our results. 
At Pian della Cavalla, palynological investigations show the presence of an open landscape during the whole recorded time period ( $\mathrm{ca}$. the last 2200 years). In particular, since c. $1300 \mathrm{AD}$, the pollen diagram shows the transition from grazed mixed woodlands to beech wooded-meadows (underlined by the increase in anthropogenic pollen indicators; Figure 5). Furthermore, the high percentages of Narcissus are connected with mowing and grazing practices (Cevasco, 2007), while the increase in microcharcoal concentrations suggests the use of controlled fires in the area.

Also, at Lago della Nava, the palynological results suggest a long-lasting land-use continuity characterised by agricultural management practices connected to the woodedmeadows system. In fact, the whole pollen sequence (about the last 1900 years) records an open landscape, characterised by herbs and shrubs typical of grazed meadows and a sparse forest cover. Furthermore, the discontinuous trend of microcharcoal concentrations suggests an irregular use of controlled fires for temporary agricultural practices or for opening up new grazing areas. In addition, between the postmedieval time and the first half of the $20^{\text {th }}$ century, the site is described as an important hub in the extensive network of transhumance routes between the coastal areas and the Apennines mountains (Moreno, Raggio, 1990; Moreno, Poggi, 1996).

At Rachixina, we interpreted the LPAZ characterised by the co-existence of trees, meadows and temporary arable lands (marked by the presence of Cerealia and by a discontinuous trend in microcharcoal concentrations) as the period of maximum spread of wooded-meadows. As already suggested by Lowe et al. (1994), this time span might correspond to the Lombard period (c. 500-600 AD).

Based on these assumptions, it is possible to conclude that - compared to the post-cultural phase - when the woodedmeadows system was in use, the pollen diagrams from Pian della Cavalla, Lago della Nava and Rachixina were characterised by (Figure 6):

- lower pollen percentages of trees and higher amounts of herbs, typical of landscapes with a predominance of open areas;

- higher pollen percentages of shrubs (according to Métailié (1981) and Canals and Sebastia (2002), Ericaceae and Juniperus are taxa normally favoured by the use of controlled fires in meadows and pastures);

- higher percentages of anthropogenic pollen indicators (i.e. - according to Behre (1981), Branch (2004), Caramiello and Arobba (2003) and Mercuri et al. (2013) - Artemisia, Cannabis, Caryophyllaceae, Centaurea cyanus, Cerealia, Chenopodiaceae, Cichorieae, Cruciferae, Galium, Papaveraceae, Plantago lanceolata, P. major/media, Rumex, Urticaceae), testifying the use of temporary agricultural practices close to the sites;

- higher values of palynological richness and thus - in agreement with Oldfield and Dearing (2003) - greater biodiversity.
For what concerns microcharcoal concentrations, their trend is quite variable within and between the sites and we have thus avoided making any generalizations.

\section{Conclusions}

By combining palynological and documentary evidence with a long-term perspective in order to investigate historical cultural landscapes, this research has allowed more light to be shed on a particular management practice that was previously widespread in the Ligurian Apennines.

In particular, our results have provided independent biostratigraphic evidence of the disappearance of landscapes that were characterized by a higher biodiversity than today, due to the past land-use activities. In all our selected sites, the abandonment of multiple management practices in connection with the wooded-meadows system, documented by the available biological, archival and oral evidence, has caused the loss of part of the environmental and cultural Ligurian heritage.

Although the three sites are today nearly abandoned, this present investigation has offered new insights for a wellinformed restoration of our cultural landscapes or, at the very least, for their proper characterisation. This particular heritage should be preserved with the reintroduction of traditional agricultural activities so as to prevent the current pattern of natural forest succession, and restore vegetation and habitat diversity. By recognising how long-term landscape transformations and exploitation of resources have shaped the structure, composition and function of present ecosystems, it is possible to appreciate the indirect role of past land-use practices (e.g. grazing, mowing, selective cutting of trees and shrubs, hay making, spring raking) in the creation and maintainance of highly biodiverse landscapes.

This study can also be considered a potential contribution to the issues of habitat management and nature-conservation policy, especially because both Lago della Nava and Rachixina are presently located in protected areas. Since the existence of this kind of landscape was strictly connected to the use of specific management practices, certain conservation actions might be included: from their integration into management plans (e.g. by reintroducing historical agricultural techniques) to the restoration and preservation of ancient pollarded trees.

\section{Acknowledgements}

The authors wish to acknowledge Diego Moreno and Roberta Cevasco for site selection and fruitful discussions. Many thanks to Maria Angela Guido and Sandra Placereani for laboratory assistance and to Bruna Ilde Menozzi for great help during the fieldwork. This research is part of Chiara Molinari's PhD thesis, within the course "Historical Geography for the Development of the Environmental and Historical Heritage" at the University of Genoa (Italy). 
Financial support was provided by the "Ministre de l'Ecologie et du Développement Durable (France)" in the framework of the project PAHF (Les paysages de l'arbre hors forêt: Multi-valorisation dans le cadre d'un développement local durable en Europe $d u$ Sud) and by the Genoa University Research Project (DISMEC-2007) "Storia topografica di sistemi agro-silvo-pastorali" led by Diego Moreno.

\section{References}

BARKLEY, F.A., 1934. The statistical theory of pollen analysis. Ecology, $15,283-89$.

BEHRE, K.E., 1981. The interpretation of anthropogenic indicators in pollen diagrams. Pollen et Spores, 23, 225-245.

BIRKS, H.J.B., and LINE, J.M., 1992. The use of rarefaction analysis for estimating palynological richness from Quaternary pollen-analytical data. The Holocene, 2, 1-10.

BRANCH, N.P, 2004. Late Würm Lateglacial and Holocene environmental History of the Ligurian Apennines, Italy. In: R. Balzaretti, C.E. Watkins, M. Pearce, eds. Ligurian landscapes, studies in archeology, geography and history. London: Accordia Reasearch Institute, pp. 7-69.

BRONK RAMSEY, C., 2005. OxCal Program v 3.10. Oxford: University of Oxford Radiocarbon Unit.

BRYANT, V.M. Jr., and HOLLOWAY, R.G., 1983. The role of palynology in archaeology. In: M.B. Schiffer, ed. Advances of Archaeological Method and Theory. New York: Academic Press, pp. 191-224.

CANALS, R.M., and SEBASTIA, M.T., 2002. Heathland dynamics in biotically disturbed areas: on the role of some features enhancing heath success. Acta Oecologica, 23, 303-312.

CARAMIELLO, R., and AROBBA, D., 2003. Manuale di archeobotanica. Milano: Franco Angeli.

CEVASCO, R., 2002. La copertura vegetale dell'alta val Trebbia nelle ricognizioni topografiche del Corpo di Stato Maggiore Sardo (18161852). Approccio storico all'ecologia dei siti. Archeologia Postmedievale, $6,195-214$.

CEVASCO, R., 2007. Memoria verde. Nuovi spazi per la geografia. Reggio Emilia: Diabasis.

CEVASCO, R., and MORENO D., 2007. Microanalisi geo-storica o geografia culturale della copertura vegetale? Sull'eredità ambientale dei "paesaggi culturali". Trame nello spazio, 3, 83-101.

DAVITE, C., and MORENO D., 1996. Des "saltus" aux "alpes" dans les Apennins du Nord (Italie). Une hypothése sur la phase du HautMoyen-Age dans le diagramme pollinique du site de Prato Spilla. In: M. Colardelle, ed. L'Homme et la Nature au Moyen Age. Actes du V Congres International d'Archéologie Médievale. Paris: Errance, pp. 138-143.

DIJKSTRA, E.F., and VAN MOURIK, J.M., 1995. Palynology of young acid forest soils in the Netherlands. Mededelingen Rijks Geologiche Dienst, 52, 283-295.

DIMBLEBY, G.W., 1957. Pollen analysis of terrestrial soils. New Phytologist, 56, 16-28.

GAVIN, D.G., and BRUBAKER, L.B., 1999. A 6000 years soil pollen record of subalpine meadow vegetation in the Olympic Mountains, Washington, USA. Journal of Ecology, 87, 106-122.

GEMIGNANI, C.A., 2013. Il Lago della Nava, storia di una zona umida. Fonti fotografiche, cartografia ed evidenze visive. In: R. Cevasco, ed. La Natura della Montagna. Sestri Levante: Oltre Edizioni, pp. 402-412.

GRIMM, E., 2015. Tilia and TGView 19 version 2.0.41 software. Springfield, USA: Illinois State Museum, Research and Collection Center.

GROVE, A.T., and RACKHAM, O., 2001. The Nature of Mediterranean Europe. An Ecological History. New Haven: Yale University Press.

GUIDO, M.A., MENOZZI, B.I., BELLINI, C., PLACEREANI, S., MONTANARI, C., 2013. A palynological contribution to the environmental archaeology of a Mediterranean mountain wetland (North West Apennines, Italy). The Holocene, 23, 1517-1527.

KUKK, T., and KULL, K., 1997. Wooded Meadows. Estonia Maritima, 2, 12-49.
KULL, K., KUKK, T., and LOTMAN, A., 2003. When culture supports biodiversity: The case of the wooded meadow. In: A. Roepstorff, N. Bubandt and K. Kull, eds. Imagining Nature: Practices of Cosmology and Identity. Århus: Ärhus University Press, pp. 76-96.

LOWE, J.J., DAVITE, C., MORENO, D., MAGGI, R., 1994. Holocene pollen stratigraphy and human interference in the woodlands of the northern Apennines, Italy. The Holocene, 4, 153-164.

MAGGI, R., and NISBET, R., 2000. Alberi da foraggio e scalvatura neolitica. Nuovi dati dalle Arene candide. In: A. Pessina, and G. Muscio, eds. La Neolitizzazione tra Oriente e Occidente. Udine: Museo Friulano di Storia Naturale, pp. 289-308.

MÉTAILIÉ, J.-P., 1981. Le feu pastoral dans les Pyrénées centrales (Barousse, Oueil, Larboust). Unpublished thesis (PhD), CNRS, Paris.

MERCURI, A.M., BANDINI MAZZANTI, M., FLORENZANO, A., MONTECCHI, M.C., RATTIGHIERI, E., TORRI, P., 2013. Anthropogenic Pollen Indicators (API) from archaeological sites as local evidence of human-induced environments in the Italian peninsula. Annali di Botanica (Roma), 3, 143-153.

MOLINARI, C., and MONTANARI, C.A, 2016. Interdisciplinary approach for reconstructing an alder-based historical agricultural practice of the Eastern Ligurian Apennines (NW Italy). Environmental Archaeology, 21, 31-44.

MOORE, P.D., WEBB J.A., and COLLINSON M.E., 1991. Pollen Analysis. 2nd ed. London: Blackwell Scientific Publications.

MORENO, D., 1990. Dal documento al terreno. Storia e archeologia dei sistemi agro-silvo-pastorali. Bologna, Il Mulino.

MORENO, D., and RAGGIO, O., 1990. The making and fall of an intensive pastoral land-use system. Eastern Liguria. $16-19^{\text {th }}$ centuries. Rivista di Studi Liguri, LVI, 193-217.

MORENO, D., POGGI, G., 1996. Storia delle risorse boschive nelle montagne mediterranee: modelli di interpretazione per le produzion foraggiere in regime consuetudinario. In: S. Cavaciocchi, ed. L'uomo e la foresta nei secoli XIII-XVIII. Firenze: Le Monnier, pp. 635-653.

NASCIMBENE, J., CASAZZA, G., BENESPERI, R., CATALANO, I., CATALDO, D., GRILlO, M., ISOCRONO, D. et al., 2016. Climate change fosters the decline of epiphytic Lobaria species in Italy. Biological Conservation, 201, 377-384.

ODGAARD, B.V., 2001. Palaeoecological perspectives on pattern and process in plant diversity and distribution adjustments: a comment on recent developments. Diversity and Distribution, 7, 197-201.

OLDFIELD, F., and DEARING, J.A., 2003. The role of human activities in past environmental change. In: K.D. Alverson, R.S. Bradley, and T.F Pedersen, eds. Paleoclimate, Global Change and the Future. Berlin: Springer, pp. 43-162.

PETERKEN, G., 2017. Recognising wood-meadows in Britain? British Wildlife, 28 (3), 155-165.

POGGI, G., 2013. "Alta risoluzione": aerofotointerpretazione e fonti orali nell'area di Fontanarossa-Monte della Cavalla. In: R. Cevasco, ed. La natura della montagna. Sestri Levante: Oltre Edizioni, pp. 345-357.

RASMUSSEN, P., 1990. Leaf foddering in the earliest Neolithic agriculture. Evidence from Switzerland and Denmark. Acta Archaeologica, 60, 71-86.

READ, H., 2000. Veteran Trees: A guide to good management. Peterborough: English Nature.

REILLE, M., 1992-1995. Pollen et spores D'Europe et D'Afrique du Nord. Laboratoire de Botanique Historique et Palynologie, Marseille, France.

REIMER, P.J., BAILLIE, M.G.L., BARD, E., BAYLISS, A., BECK, J.W., BERTRAND, C.J. H., BLACKWELL, P.G. et al., 2004. IntCa104 terrestrial radiocarbon age calibration, 0-26 cal kyr BP. Radiocarbon, 46, 1029-58.

ROLSTAD, J., GJERDE, I., STORAUNET, K.O., and ROLSTAD, E., 2001. Epiphytic lichens in Norwegian coastal spruce forest: historic logging and present forest structure. Ecological Applications, 11, 421-436.

SEGERSTRÖM, U., 1991. Soil pollen analysis - An application for Tracing Ancient Arable Patches. Journal of Archaeological Science, 18, 165-175.

SIGAUT, F., 1982. Gli alberi da foraggio in Europa: significato tecnico ed economico. Quaderni Storici, 17, 49-58.

STOCKMARR, J., 1971. Tablets with spores used in absolute pollen analysis. Pollen et Spores, 13, 615-621.

THUNJAI, T., and BOYD, C.E., 2001. Pond soil pH measurement. Journal of the World Aquaculture Society, 32, 141-152.

WILMSHURST, J.M., and MCGLONE, M.S., 2005. Corroded pollen and spores as indicators of changing lake sediment sources and catchmen disturbance. Journal of Paleolimnology, 34, 503 -517. 
